\title{
Chemical Bonds of Cations in Grapevine Berries and Stems of Some Important Cultivars of Vitis vinifera (L.) and Their Relevance for Viticulture and Enology
}

\author{
Klaus SCHALLER* and Ruth LEHNHART \\ Geisenheim University, Department of Applied Biology, P.O.B. 1154, D-65366 Geisenheim, Germany \\ *)Corresponding author, e-mail: klaus.schaller@hs-gm.de
}

BulletinUASVM Horticulture 73(2) / 2016

Print ISSN 1843-5254, Electronic ISSN 1843-5394

DOI:10.15835/buasvmcn-hort:12027

\begin{abstract}
Cations are essential for plant growth, tissue build-up and its stabilization. Divalent cations are necessary for cell wall stability and other interstitial tissues. They may be cross-linked with pectins or form looser ionic bindings. This is of importance for grape processing during the technical operations of juice extraction. Monovalent ions are more involved in vacuolar homeostasis and $\mathrm{pH}$ stabilization. With a specific extraction procedure $\mathrm{H}_{2} \mathrm{O}$-soluble, $1 \mathrm{~N}$ $\mathrm{NaCl}$-soluble, $2 \% \mathrm{CH}_{3} \mathrm{COOH}$-soluble, and $5 \% \mathrm{HCl}$-soluble fractions as well as the total content of $\mathrm{K}$, Ca, and $\mathrm{Mg}$ were analyzed in grapevine berries and stems. In berries as well as in stems the monovalent $\mathrm{K}$ is only found in the water and the $\mathrm{NaCl}$ fraction. But only $50-60 \%$ of the total $\mathrm{K}$ can be extracted with both solutes. The divalent cation Ca is found in all four fractions with differing amounts, but water soluble Ca is in most cases highest. Ca may also have an indicator value for BSN, because the water soluble fraction is lowest in the most susceptible variety Riesling. Mg is not found in $\mathrm{HCl}$ fraction. An analysis of variance shows that the varieties have a significant influence on nutrient distribution in different tissues. It seems that the relation $\mathrm{Ca} / \mathrm{Mg}(\mathrm{NaCl}$ fraction) in stems is a good indicator for BSN because susceptible varieties show lower ratios than resistant ones. Some more research is necessary to clear up this possible relationship.
\end{abstract}

Keywords: bunches, bunch stem necrosis (BSN), grapevine, nutrient fractions, stems

\section{INTRODUCTION}

Cations have different functions in plant cells and tissues: maintain vacuolar homeostasis, stabilize cell $\mathrm{pH}$, activate diverse enzymes, stabilize cell walls via cross-linking of pectins etc. which is well described in all important textbooks for plant nutrition (Marschner 2011; Mengel and Kirkby, 2007).

Fruits are important sources for mineral nutrients (MN) in our daily diet as well as vitamins and other valuable compounds used for direct human consumption and also processed foods (Souci-Fachmann-Kraut, 2008). For plants it is a given that $\mathrm{MN}$ are essential for their growth and are constitutive elements of organelles, cell walls, enzymes etc. (Epstein-Bloom 2005; Marschner
2011; Mengel and Kirkby 2007). MN can improve the resistance of plants to fungi diseases. Most promising results exist for potassium and calcium (Datnoff et al. 2007). Both elements are discussed concerning the incidence of bunch stem necrosis (BSN) in susceptible cultivars like Riesling, Mueller-Thurgau and Pinot Noir (Hiffny and Alleweldt 1972; Stellwaag 1967; Theiler and Müller 1986).

In case of grape processing into must (juice) and wine, cations are partly responsible for the wines' buffer system, which guaranties an undisturbed fermentation. Screening the most widely used textbooks of wine chemistry concerning mineral composition of berries and stems the information is not as good as expected. 
Tab. 1. Total potassium and its fractions in berries of different cultivars (mmole $\mathrm{K} / \mathrm{kg} \mathrm{dm}$ )

\begin{tabular}{cccccc}
\hline Fraction & Riesling & Silvaner & Ehrenfelser & Reichensteiner & Mueller-Thurgau \\
\hline $\mathrm{H}_{2} \mathrm{O}$-soluble & $24.62 \mathrm{a}$ & $33.06 \mathrm{be}$ & $29.41 \mathrm{~cd}$ & $28.97 \mathrm{~d}$ & $32.93 \mathrm{e}$ \\
\hline 1N NaCl-soluble & 2.81 & 2.88 & 3.45 & 3.07 & 3.77 \\
\hline Total & $42.20 \mathrm{a}$ & $45.65 \mathrm{~b}$ & $42.71 \mathrm{ac}$ & $37.82 \mathrm{~d}$ & $42.97 \mathrm{ace}$ \\
\hline
\end{tabular}

There exist some good compilations about MN in wines and their ranges (Blouin and Cruège 2013; Usseglio-Tomasett 1989; Würdig and Woller 1989). In all publications only total MN contents are reported.

MN may also have some sensorial effects in a finished wine; but it is up to now not completely proven how the interaction with other organic compounds e.g. acids, may lead to such sensations. Sometimes is reported that higher potassium content give wines a creamy sensation. Following the processing line for winemaking it is important which steps are used for juice extraction: mashing or whole bunch pressing, maceration time, pressing programs including differing pressure steps. Hence, by varying these operational steps, MN may be extracted in variable amounts into the must. Influence of cultivars may be also important. No scientific papers exist about the fractionation about mono- and divalent cations in berries and stems of grapevines.

Taking into account these above mentioned problems a study was initiated to get more information about chemical bonding of cations in berries and stems and cultivar's behavior.

\section{MATERIALS AND METHODS}

For the experiment 5 white wine cultivars, all grafted on rootstock $5 \mathrm{C}$, were used: 1 . Riesling (clone 239) [RI], 2. Silvaner [SI], 3. Ehrenfelser (crossbred RI x SI) [EHR], Reichensteiner (crossbred Mueller-Thurgau x (Madeleine Angevine $\mathrm{x}$ Calabreser Frölich)) [REI], Mueller-Thurgau (crossbred Riesling x Madeleine Royale) [MUE]. RI, SI, EHR and REI were cultivated in test field G and MUE in test field D of the Department of Grapevine Breeding and Grafting. All varieties were planted in 4 replications. Every replication contained 12 grapevines. Soil in both fields is a deep loess derived "Parabraunerde" (chromic luvisol) with high fertility status.

Sampling: bunches were picked at technological ripeness, transferred to the lab, separated in stems and berries, shock frozen with liquid nitrogen and stored in a deep freezer until analysis.

Sample preparation: Prior to analysis berries were cut with a scalpel into halves and kernels removed from the pulp. Stems were cut into small pieces.

Extraction of cations: Extraction of cations from the different tissues follows the scheme according shown in fig 1 . Potassium (K) was determined by flame photometry: Calcium (Ca) and magnesium (Mg) by Atomic Absorption Spectrophotometry (AAS). Concentrations are reported in mmole $/ \mathrm{kg} \mathrm{dm}$. Results for the different nutrients and their nutrient fractions were analyzed after testing for homogeneity with a one way respectively two way Anova.

\section{RESULTS AND DISCUSSIONS}

1. Potassium (K)

Berries: $\mathrm{K}$ is not covalently bound in any organic structures in cells and organelles i.e. after rupture of tissues and cells it will leak into the surrounding fluids. In general $\mathrm{K}$ increases the permeability of cell walls and tissues because of its hydrations effects. According to our proposed extraction procedure and the general findings in the literature $\mathrm{K}$ should be nearly complete soluble in water (Marschner 2011). Table 1 shows the distribution of $\mathrm{K}$ in the water soluble and $\mathrm{NaCl}$ soluble fraction.

Highest amounts are found in the $\mathrm{H}_{2} \mathrm{O}$-fraction ranging from $24.6 \mathrm{mmole} \mathrm{K} / \mathrm{kg} \mathrm{dm}$ in $\mathrm{RI}$ to 33.1 mmole $\mathrm{K} / \mathrm{kg} \mathrm{dm}$ in SI. The remaining cultivars EHR, REI and MUE are grouped in between both extremes. $\mathrm{K}$ in the $\mathrm{NaCl}$-fraction is remarkably lower in all cultivars. They range from $2.81 \mathrm{mmole}$ $\mathrm{K} / \mathrm{kg} \mathrm{dm}$ in RI to $3.77 \mathrm{mmole} \mathrm{K} / \mathrm{kg} \mathrm{dm}$ in MUE. This fraction accounts only for $8-12 \%$ of the $\mathrm{H}_{2} \mathrm{O}$-soluble K. No significant difference between cultivars could be found. The remaining fractions acetic acid and $\mathrm{HCl}$ did not contain any $\mathrm{K}$. In contrast to the assumption that $\mathrm{K}$ should be completely found in the first two fractions only $65-85 \%$ of total $\mathrm{K}$ can be extracted with the solutes. If the remaining 


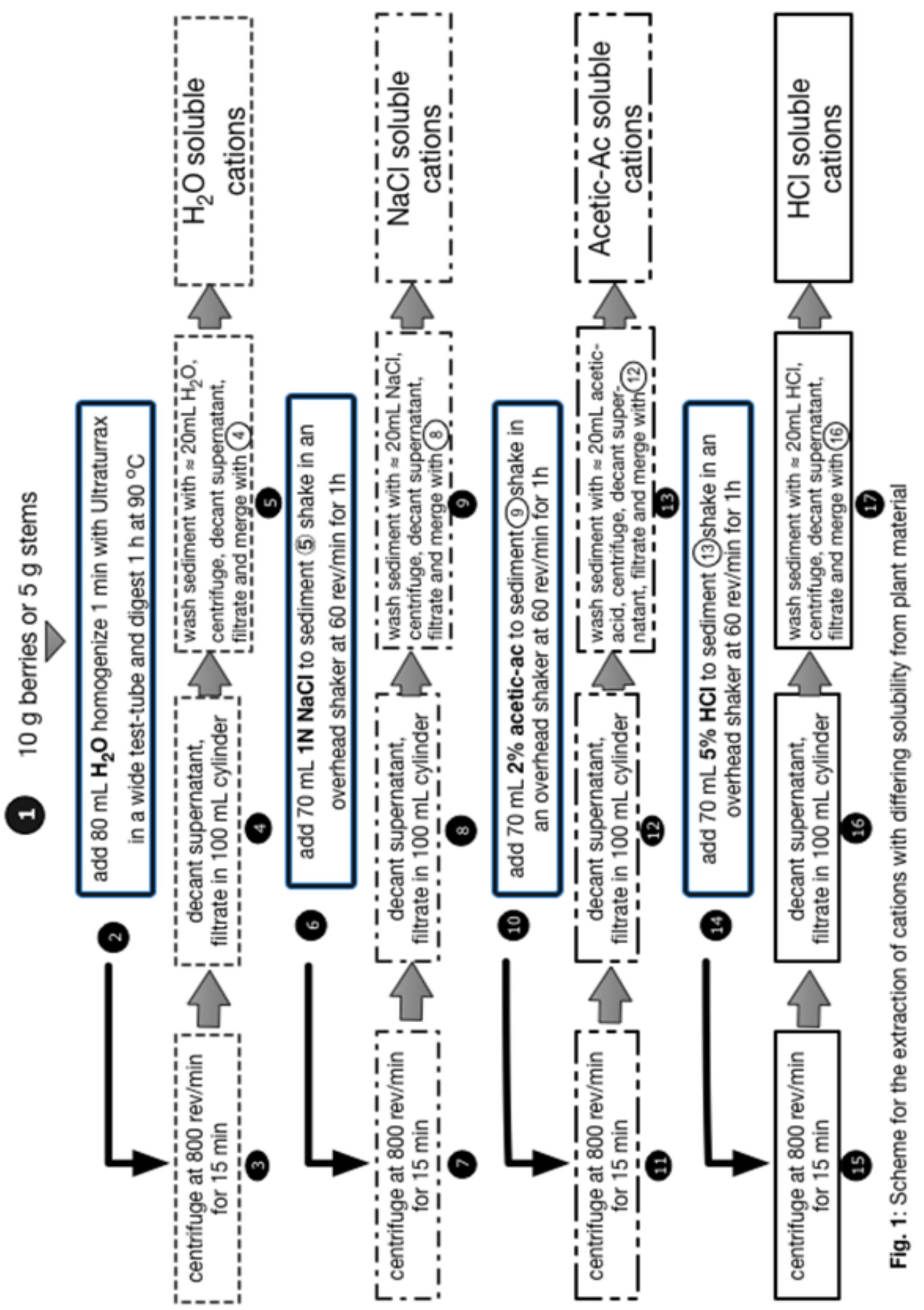


Tab. 2. Total potassium and its fractions in stems of different cultivars (mmole $\mathrm{K} / \mathrm{kg} \mathrm{dm}$ )

\begin{tabular}{cccccc}
\hline Fraction & Riesling & Silvaner & Ehrenfelser & Reichensteiner & Mueller-Thurgau \\
\hline $\mathrm{H}_{2} \mathrm{O}$-soluble & $32.29 \mathrm{a}$ & $47.64 \mathrm{~b}$ & $39.90 \mathrm{c}$ & $33.38 \mathrm{ad}$ & $35.67 \mathrm{~d}$ \\
\hline $1 \mathrm{~N} \mathrm{NaCl}-$-soluble & $7.10 \mathrm{a}$ & $16.11 \mathrm{~b}$ & $8.18 \mathrm{~cd}$ & $8.18 \mathrm{~d}$ & $8.89 \mathrm{~d}$ \\
\hline Total & $56.08 \mathrm{a}$ & $63.75 \mathrm{~b}$ & $48.08 \mathrm{c}$ & $49.36 \mathrm{~cd}$ & $58.31 \mathrm{e}$ \\
\hline Note: Different letters between cultivars denote significant differences (LSD test. $\mathrm{c}<0.05)$. &
\end{tabular}

Tab.3. Total calcium and its fractions in berries of different cultivars (mmole $\mathrm{Ca} / \mathrm{kg} \mathrm{dm}$ )

\begin{tabular}{cccccc}
\hline Fraction & Riesling & Silvaner & Ehrenfelser & Reichensteiner & Mueller-Thurgau \\
\hline $\mathrm{H}_{2} \mathrm{O}$-soluble & $2.03 \mathrm{a}$ & $2.18 \mathrm{ab}$ & $2.50 \mathrm{bc}$ & $1.79 \mathrm{~d}$ & $2.20 \mathrm{ac}$ \\
\hline $1 \mathrm{~N} \mathrm{NaCl}-$ soluble & $0.59 \mathrm{a}$ & $0.54 \mathrm{~b}$ & $0.49 \mathrm{bcd}$ & $0.41 \mathrm{~d}$ & $0.55 \mathrm{c}$ \\
\hline $2 \% \mathrm{Acetic}$ acid & $1.01 \mathrm{a}$ & $0.84 \mathrm{ab}$ & $0.99 \mathrm{abc}$ & $0.78 \mathrm{acd}$ & $1.66 \mathrm{e}$ \\
\hline $5 \% \mathrm{HCl}$ & 0.53 & 0.48 & 0.54 & 0.52 & 0.49 \\
\hline Total & $4.14 \mathrm{a}$ & $4.04 \mathrm{abd}$ & $4.52 \mathrm{abce}$ & $3.55 \mathrm{ad}$ & $4.90 \mathrm{e}$ \\
\hline Note: Different letters between cultivars denote significant differences (LSD test. $<<0.05)$.
\end{tabular}

$\mathrm{K}$ may be complexed or bound in some structures which may prevent a complete extraction stays up to now un-answered. The assumption seems not conclusive because $\mathrm{K}$ should be found in the following extractants with a stronger extraction and exchange capacity.

Significant differences between cultivars are indicated in table 1 with exception of MUE vers. SI and REI vers. EHR all varieties are significantly different. $\mathrm{NaCl}$ extracted $\mathrm{K}$ is not significant for all cultivars. Total $\mathrm{K}$ content in berries is probably a varietal characteristic (table 1). Lowest content is found in REI (37.8 mmole $\mathrm{K} / \mathrm{kg} \mathrm{dm}$ ) and highest in SI (45.7 mmole K/ $\mathrm{kg} \mathrm{dm}$. Differences between RI, SI and REI are significant. Percentage of watersoluble $\mathrm{K}$ on total $\mathrm{K}$ demonstrates that the lowest amount is found in RI (58\%) and the highest in SI (82\%); the remaining cultivars EHR, REI and MUE range from $66.5-76.7 \%$.

\section{Stems}

Stems have no influence on quality in red wine processing because prior to fermentation and crushing bunches are de-stemmed. In contrast, during white wine production it is possible that they can exert influence on must composition. In a more positive sense they will improve the drainage of must out of the press cake but then stems are immersed in the drain-off must and possibility exists that cations from stems can leak or diffuse in the surrounding solute. The probability for such a process increases when stems are broken down during transport and pumping into the press.
Besides these technological facts mineral nutrient content of stems may also have an important effect on the physiological disorder called "bunch stem necrosis" (BSN), "dessèchement de la rafle" or "Stiellaehme" (Hiffny 1972, StellwaagKittler 1967, Theiler 1986). Stems are getting necrotic and the transport of sugars and solutes into berries is restricted. As a consequence berries will shrivel, having a low sugar and high acidity content. Expected wine quality may be minor. Table 2 presents the $\mathrm{K}$ content of the different fractions in stems of the tested cultivars.

Lowest $\mathrm{H}_{2} \mathrm{O}$-soluble $\mathrm{K}$ has RI $(32.3 \mathrm{mmole} / \mathrm{kg}$ $\mathrm{dm}$ ), followed by REI (33.8 mmole $\mathrm{K} / \mathrm{kg} \mathrm{dm}$ ) and MUE (35.7 mmole $\mathrm{K} / \mathrm{kg} \mathrm{dm}$ ). RI is significantly different from vers. SI, EHR and MUE. Other research reveals that RI and MUE are strongly prone to BSN (Hiffny and Alleweldt 1972, Theiler and Müller 1986). If $K$ is solely responsible for the incidence of BSN is not yet proven. In the fraction of $\mathrm{NaCl}$-soluble K RI has the lowest content whereas that of SI is more than doubled. If $\mathrm{K}$ alone may act as an indicator for BSN is still strongly called into question.

On the other site stems may also contribute to the K load of must depending on their mechanical stress during must extraction especially in white wine processing.

\section{Calcium (Ca) \\ Berries}

Calcium is an important nutrient because it is responsible for stability of cell walls, integrity of 
Tab.4. Total calcium and its fractions in stems of different cultivars (mmole $\mathrm{Ca} / \mathrm{kg} \mathrm{dm}$ )

\begin{tabular}{cccccc}
\hline Fraction & Riesling & Silvaner & Ehrenfelser & Reichensteiner & Mueller-Thurgau \\
\hline $\mathrm{H}_{2} \mathrm{O}$-soluble & $4.14 \mathrm{a}$ & $7.17 \mathrm{~b}$ & $5.48 \mathrm{bc}$ & $4.73 \mathrm{abcd}$ & $5.14 \mathrm{bcd}$ \\
\hline $1 \mathrm{~N} \mathrm{NaCl}-$ soluble & 0.60 & 0.68 & 0.59 & 0.47 & 0.57 \\
\hline $2 \% \mathrm{Acetic}$ acid & $1.75 \mathrm{a}$ & $2.10 \mathrm{~b}$ & $1.68 \mathrm{ac}$ & $1.51 \mathrm{~d}$ & $1.59 \mathrm{ac}$ \\
\hline $5 \% \mathrm{HCl}$ & $1.66 \mathrm{abd}$ & $1.87 \mathrm{bdc}$ & $1.94 \mathrm{adc}$ & $1.46 \mathrm{de}$ & $1.15 \mathrm{e}$ \\
\hline Total & $8.18 \mathrm{a}$ & $11.82 \mathrm{~b}$ & $9.69 \mathrm{ace}$ & $7.81 \mathrm{ad}$ & $8.45 \mathrm{a}$ \\
\hline Note: Different letters between cultivars denote significant differences (LSD test. $\mathrm{p}<0.05)$.
\end{tabular}

Tab.5. Total magnesium and its fractions in berries of different cultivars (mmole $\mathrm{Mg} / \mathrm{kg} \mathrm{dm}$ )

\begin{tabular}{cccccc}
\hline Fraction & Riesling & Silvaner & Ehrenfelser & Reichensteiner & Mueller-Thurgau \\
\hline $\mathrm{H}_{2} \mathrm{O}-$ soluble & $1.74 \mathrm{a}$ & $2.84 \mathrm{bc}$ & $2.61 \mathrm{c}$ & $2.09 \mathrm{~d}$ & $2.53 \mathrm{ce}$ \\
\hline $1 \mathrm{~N} \mathrm{NaCl}$-soluble & 0.29 & 0.25 & 0.22 & 0.25 & 0.27 \\
\hline $2 \%$ Acetic acid & $0.17 \mathrm{abe}$ & $0.17 \mathrm{bce}$ & $0.16 \mathrm{cba}$ & $0.14 \mathrm{abcd}$ & $0.20 \mathrm{e}$ \\
\hline Total & $2.20 \mathrm{a}$ & $3.25 \mathrm{~b}$ & $2.93 \mathrm{c}$ & $2.48 \mathrm{ad}$ & $3.00 \mathrm{bce}$ \\
\hline Note: Different letters between cultivars denote significant differences (LSD test. $\mathrm{p}<0.05$ ).
\end{tabular}

membranes, as well as their permeability. Therefore one can expect in contrast to $\mathrm{K}$ that it is not only available in a water- or $\mathrm{NaCl}$-soluble form. Table 3 demonstrates that $\mathrm{Ca}$ is found in four different fractions.

As with $\mathrm{K}$, the main fraction for $\mathrm{Ca}$ is the water soluble one. Nearly $50 \%$ of the total Ca is located in that fraction; the range is $44.9-55.3 \%$ ). Second place holds acetic acid soluble $\mathrm{Ca}$; $\mathrm{NaCl}-$ and $\mathrm{HCl}$-soluble have similar contents ranging between 0.41 mmole and 0.59 mmole $\mathrm{Ca} / \mathrm{kg}$ $\mathrm{dm}$. Ca content in berries represent roughly one tenth of their total $\mathrm{K}$ content. The tested cultivars differ significantly between each other, which is indicated in table 3 . $\mathrm{HCl}$-soluble fraction shows no significant differences.

\section{Stems}

Total Ca content in stems shows a great span from 7.81 mmole in REI till 11.82 mmole $\mathrm{Ca} / \mathrm{kg}$ $\mathrm{dm}$ in SI. RI has also a low Ca content with 8.18 mmole $\mathrm{Ca} / \mathrm{kg} \mathrm{dm}$. Comparing stems' Ca content to berries it is $1.7-2.9$ times higher (Tab. 4).

The water soluble fraction is lowest in RI (4.14 mmole $\mathrm{Ca} / \mathrm{kg} \mathrm{dm}$ ); except the cultivar REI, all other are significantly different to Riesling. $\mathrm{NaCl}-$ soluble Ca shows no differentiation between the tested cultivars, but then in the acetic acid fraction clear differences exists. Again SI has the highest values with $2.10 \mathrm{mmole} \mathrm{Ca} / \mathrm{kg} \mathrm{dm}$. Both REI and MUE range lowest. In the $\mathrm{HCl}$-fraction RI, SI and EHR are close together (1.66 - 1.94 mmole Ca/kg $\mathrm{dm})$, whereas REI and MUE are in the low range with 1.15-1.46 mmole $\mathrm{Ca} / \mathrm{kg} \mathrm{dm}$. Water soluble Ca in stems may also have an indicator value for BSN because the most sensitive cultivar RI has the lowest concentration in stems.

\section{Magnesium (Mg)}

\section{Berries}

The total Mg content in berries is found for RI (2.20 mmole $\mathrm{Mg} / \mathrm{kg} \mathrm{dm}$ ). With exception of REI al other cultivars are significantly different from RI (table 5). The water soluble fraction is again the lowest in RI (mmole $\mathrm{Mg} / \mathrm{kg} \mathrm{dm}$ ) and significantly different from all other tested cultivars.

The ratio between total $\mathrm{K}$ in berries/total $\mathrm{Mg}$ in berries varies from 14.0 in SI to 19.2 in RI. The ration of water soluble $\mathrm{K}$ in berries/water soluble $\mathrm{Mg}$ in berries is widest in RI with 19.2 whereas SI, EHR, REI and MUE are very close together; the span is from 14.o to 15.3.

\section{Stems}

Total Mg content in stems varies from 3.70 to $5.98 \mathrm{mmole} \mathrm{Mg} / \mathrm{kg} \mathrm{dm}$ dependent on cultivar (Tab.6.).

Both, RI and EHR rank lowest whereas SI, REI and MUE are significantly higher. The water soluble fraction shows a similar distribution: RI, EHR and MUE rank lowest (2.75 - 3.16 mmole Mg/ $\mathrm{kg} \mathrm{dm}$ ). SI and REI are significantly higher: 4.54$4.99 \mathrm{mmole} \mathrm{Mg} / \mathrm{kg} \mathrm{dm}$. In the $\mathrm{NaCl}$-fraction RI, REI and MUE are highest. 
Tab.6. Total magnesium and its fractions in stems of different cultivars (mmole $\mathrm{Mg} / \mathrm{kg} \mathrm{dm}$ )

\begin{tabular}{cccccc}
\hline Fraction & Riesling & Silvaner & Ehrenfelser & Reichensteiner & Mueller-Thurgau \\
\hline $\mathrm{H}_{2} \mathrm{O}-$ soluble & $2.75 \mathrm{a}$ & $4.54 \mathrm{~b}$ & $3.03 \mathrm{ac}$ & $4.99 \mathrm{cad}$ & $3.16 \mathrm{ce}$ \\
\hline $1 \mathrm{~N} \mathrm{NaCl}-$-soluble & $0.70 \mathrm{ab}$ & $0.64 \mathrm{~b}$ & $0.46 \mathrm{c}$ & $0.77 \mathrm{ad}$ & $0.70 \mathrm{ace}$ \\
\hline $2 \%$ Acetic acid & $0.26 \mathrm{a}$ & $0.40 \mathrm{~b}$ & $0.22 \mathrm{ac}$ & $0.21 \mathrm{acde}$ & $0.25 \mathrm{ace}$ \\
\hline Total & $3.72 \mathrm{ac}$ & $5.51 \mathrm{~b}$ & $3.70 \mathrm{c}$ & $5.98 \mathrm{~d}$ & $4.16 \mathrm{ce}$ \\
\hline Note: Different letters between cultivars denote significant differences (LSD test. $\mathrm{p}<0.05)$.
\end{tabular}

Tab.7. Nutrient ratios in stems and its different fractions of different cultivars

\begin{tabular}{|c|c|c|c|c|c|}
\hline Fraction & Riesling & Silvaner & Ehrenfelser & Reichensteiner & Mueller-Thurgau \\
\hline \multicolumn{6}{|c|}{$\mathrm{K} / \mathrm{Mg}$} \\
\hline $\mathrm{H}_{2} \mathrm{O}$-soluble & 7.8ac & $6.9 \mathrm{ab}$ & $7.5 \mathrm{bc}$ & $7.1 \mathrm{~b}$ & $7.0 \mathrm{~b}$ \\
\hline $1 \mathrm{~N} \mathrm{NaCl}$-soluble & $10.1 \mathrm{a}$ & $25.2 \mathrm{~b}$ & $17.4 \mathrm{c}$ & $9.2 \mathrm{a}$ & $12.7 \mathrm{a}$ \\
\hline Total & $15.5 \mathrm{a}$ & $12.1 \mathrm{~b} \mathrm{a}$ & $13.4 \mathrm{ca}$ & $8.4 \mathrm{~b}$ & $14.6 \mathrm{a}$ \\
\hline \multicolumn{6}{|c|}{$\mathrm{K} / \sqrt{\mathrm{Ca}+\mathrm{Mg}}$} \\
\hline $\mathrm{H}_{2} \mathrm{O}$-soluble & $12,3 \mathrm{a}$ & $14.0 \mathrm{~b}$ & $12.8 \mathrm{ab}$ & $10.7 \mathrm{c}$ & $12.5 \mathrm{a}$ \\
\hline $1 \mathrm{~N} \mathrm{NaCl}$-soluble & $6.2 \mathrm{a}$ & $14.0 \mathrm{~b}$ & $7.9 \mathrm{ac}$ & $7.3 \mathrm{ca}$ & $7.9 \mathrm{c}$ \\
\hline Total & $16.3 \mathrm{a}$ & $15.4 \mathrm{bc}$ & $13.2 \mathrm{c}$ & $13.3 \mathrm{c}$ & $16.5 \mathrm{a}$ \\
\hline \multicolumn{6}{|c|}{$\mathrm{Ca} / \mathrm{Mg}$} \\
\hline $\mathrm{H}_{2} \mathrm{O}$-soluble & $1.55 \mathrm{ab}$ & $1.59 \mathrm{ab}$ & $1.85 \mathrm{ac}$ & $0.98 \mathrm{a}$ & $1.69 \mathrm{c}$ \\
\hline $1 \mathrm{~N} \mathrm{NaCl}$-soluble & $0.87 \mathrm{a}$ & $1.07 \mathrm{~b}$ & $1.30 \mathrm{c}$ & $0.64 d$ & $0.83 a$ \\
\hline Total & $2.26 \mathrm{a}$ & $2.16 \mathrm{a}$ & $2.69 \mathrm{~b}$ & $1.34 \mathrm{c}$ & $2.09 \mathrm{a}$ \\
\hline
\end{tabular}

Water soluble and $\mathrm{NaCl}$-fraction together combine more than $90.5 \%$ of the total $\mathrm{Mg}$ content. The ratio of total $\mathrm{K} / \mathrm{Mg}$ (table 7 ) is highest in RI and MUE, 15.5 respectively 14.6. In SI, EHR, and REI are all lower viz. 12.1, 13.4 and 8.4, that means in RI and MUE is a strong dominance of $\mathrm{K}$ over $\mathrm{Ca}$ and $\mathrm{Mg}$, in other words the tissue has probably a higher permeability. For instance cations may leach out of tissues if adverse weather conditions favor permanent moistening of stems. It is also possible that oxygen diffuses in the tissues and can initiate adverse oxidation processes with the help of phenol-oxidases resulting in its damage.

In the water soluble $\mathrm{K} / \mathrm{Mg}$ fraction only $\mathrm{RI}$ differ vers. REI and MUE and the differentiation of the measured values is not very strong. In contrast $\mathrm{K} / \mathrm{Mg}$ ratios in the $\mathrm{NaCl}$-fraction differ very clearly. RI together with REI and MUE form a group with low $\mathrm{K} / \mathrm{Mg}$ values in contrast to SI and EHR with very high values.

In soil science exists a formula in order to describe the interaction of $\mathrm{K}$ to $\mathrm{Ca}+\mathrm{Mg}$ as a flocculating and/or dispersing agent which was also trans- ferred to plant physiology. It shall characterize the status of tissues concerning their permeability.

The term $\frac{\mathrm{K}}{\sqrt{\mathrm{Ca}+\mathrm{Mg}}}$

was cal-culated for both water soluble and $\mathrm{NaCl}$ fractions including the total contents in stems. Results are shown in table 7. The calculation for the total elements values show that the highest amounts are found in RI, MUE and SI with 16.3, 16.5 and 15.4 respectively. High values indicate that $\mathrm{K}$ dominates over $(\mathrm{Ca}+\mathrm{Mg})$ and is a measure for the stability of membranes and/or tissues (Marschner and Mengel 1966). The findings for the water soluble fraction as well as the total amounts are not really compelling, because a differentiation between susceptible cultivars (RI and MUE) and non-susceptible ones is not possible.

Comparing both the characteristics of $\mathrm{Ca}$ and $\mathrm{Mg}$ in physiology there exist some major differences: Ca stabilizes mainly cell walls, middle lamellas and other supporting tissues and is involved to a minor, but very important part in 


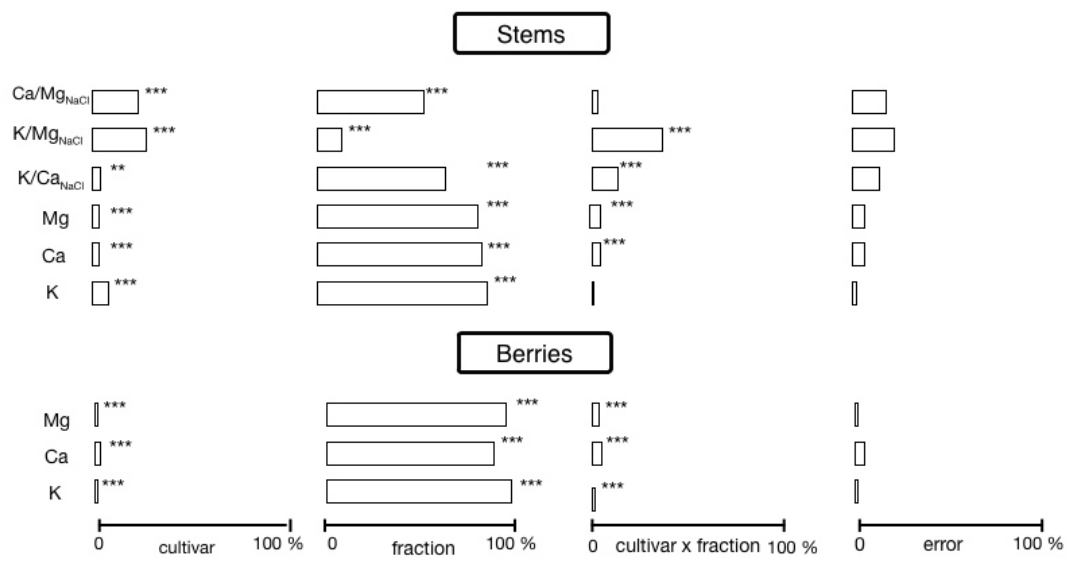

Fig.2. Breakdown of total variance for mineral nutrients in berries and stems and their partitioning on cultivar, nutrient fraction, interaction, and unexplained variance (\%).

signaling stress e.g. drought, light, pathogens etc. (Tuteja, 2007). Mg has functional tasks as central ion in chlorophyll and can also overtake some unspecific functions of Ca i.e. stabilizing cell walls.

Taking these thoughts into account it should be promising to form a ratio between $\mathrm{Ca} / \mathrm{Mg}$ because changes could probably indicate if $\mathrm{Ca}$ is lost from its main functions i.e. strengthening the cell wall system. As can be seen in table 7 , these interactions between both nutrients seem to be a criterion in order to discriminate between cultivars. The water soluble fraction, which represent nutrients found in the cytosol and also the free space of the tissues indicates no clear differentiation as well as the ratios calculated with the total content. However, the $\mathrm{NaCl}$ fraction, which represents the exchangeable parts of both nutrients differentiate the cultivars very clearly. In both susceptible cultivars RI and MUE the ratio is very low, i.e. dominance of Mg over Ca and in SI and EHR the more robust cultivars, it is significantly higher.

Assessing the complete system of nutrients in berries and stems with help of a two way ANOVA is shown in fig. 2. The cultivars' influence on $\mathrm{K}$, $\mathrm{Ca}$, and $\mathrm{Mg}$ content in berries is significant but small; the main part of variance is loaded in the fraction. The interaction as well as the error term as also very small. It is therefore the technological process, which is responsible for the transfer of the main cations into the must. This is important when musts or wines are examined for inorganic constituents by official authorities.
The composition of stems my have a minor influence on must nutrients, except by strong mechanical stresses during transport and handling prior to pressing. In that case the accumulation of $\mathrm{K}, \mathrm{Ca}$, and $\mathrm{Mg}$ is a little bit more influenced by cultivar in comparison to berries, but the main load of variance is in the factor "fraction".

That means that handling can exert some influence on the cation transfer into musts. As stated above, mineral nutrients in stems may also have an influence on stems' health. Bunch stem necrosis is a much feared disease which may be responsible for yield and quality losses. Fig. 3 shows a bunch of Italian Riesling with severe symptoms of BSN. In the lower part of the bunch the berries shrinkle and are partly infected by Botrytis. It is obvious that such grape material is not very well suited for wine making.

From these findings it may be argued that Ca uptake, its transport and localization in different organs is genetically controlled. This is in agreement with Pooviah (1979) and Dodd et al. (2010). In ripening fruits an interchange of bound and soluble $\mathrm{Ca}$ in pericarp tissue of tomatoes occurs. A lot of scientific studies exist about the development and ripening of fruits (Ulrich 1952). In addition Solomos and Laties (1973) studied avocado, Suwwann and Pooviah (1978) tomatoes, Fils-Lycaon and Buret (1990) cherries and Hallet et al. (1992) kiwis. Early studies about grapevine ripening dealt only with sugars, acids and phenolic compounds (Kriedemann 1969, Hardy 1967, Pirie and Mullins 1986). 


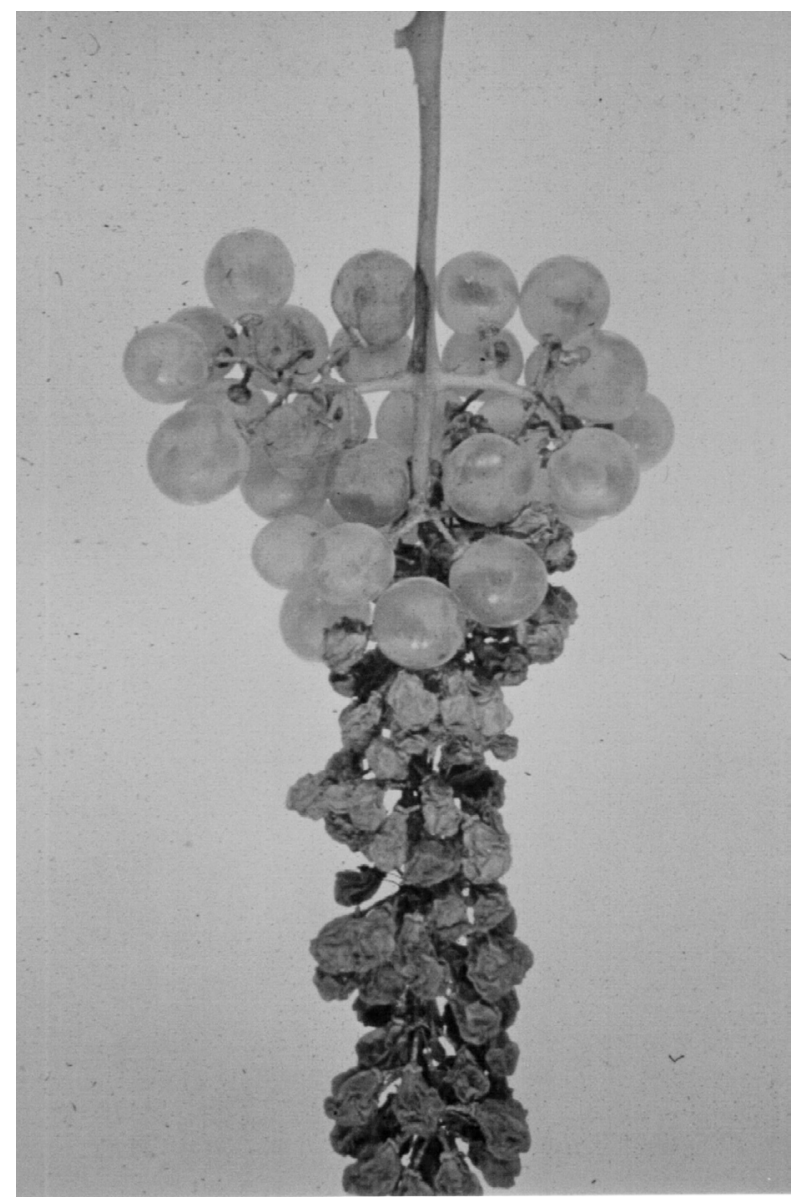

Fig.3. Bunch stem necrosis in Italian Riesling (by courtesy of Dr. G. Brendel, Geisenheim University)

Similar processes may also happen during bunch development and ripening of grapes. Further research seems necessary, on a time axis to verify these assumptions.

\section{CONCLUSION}

The evolution of cations in berries and stems was hardly in the focus of studies, because the common idea was that there exists no direct influence on the vinification process. Nevertheless, cation absorption is directly connected with organic acid synthesis which are important for vinification and conservation of wines. Only the accumulation of potassium got some notice, because of its influence on $\mathrm{pH}$ and its interaction with tartaric acid.

In a field test with 5 varieties (Riesling, Silvaner, Mueller-Thurgau, Ehrenfelser and Reichensteiner) the cations $\mathrm{K}, \mathrm{Mg}$ and Ca were analyzed in berries and stems. It could be demonstrated that the tested varieties differ in their ability to accumulate the above mentioned cations in both organs. Much stronger is the differentiation between varieties when nutrient fractions are compared. It can be seen that the chemical bonds of $\mathrm{K}, \mathrm{Mg}$ and Ca differ in a wide range in the fractions. It is possible that with varying extraction or pressure techniques the mineral composition of must may vary and with the variety in use. An influence on wine quality may be expected but has to be proven in future investigations. The slightly exchangeable fractions of $\mathrm{K}$ and $\mathrm{Mg}$ have probably a strong effect on the incidence of BSN in susceptible varieties. There is no doubt about the importance of mineral nutrient on berry and stem health and their importance for wine quality as well as the yield and quality potential.

Mineral nutrients in different organs of grapevine bunches should attract more notice in order to get more information about their influence on bunch soundness and the final wine quality. Research on these topics needs to be intensified. 


\section{REFERENCES}

1. Alleweldt G and Hifny H A A (1972). Studies on grape stalk necrosis. II. Analysis of the causes of the disease. Vitis 11: 10-28.

2. Blouin J and Cruège J (2013). Analyse et Composition des Vins. Dunod, Paris.

3. Datnoff L E, Rodrigues F A, Seebold K W (2007). Silicon and plant disease. In: Mineral nutrition and plant disease. Eds. Datnoff, L.E., Elmer, W.H. and Huber D.M.. St. Paul, MN, USA: The American Phytopathological Society.

4. Dodd A N, Kudla J and Sanders D (2010). The language of calcium signaling. Annu. Rev. Plant Biol. 61, 539-620.

5. Epstein E and Bloom A J (2005). Mineral Nutrition of Plants: Principles and Perspectives. 2nd ed. Sinauer Associates, Inc. Publishers. Sunderland, MA, USA.

6. Fils-Lycaon B and Buret M (1990). Loss of firmness and changes in pectic fractions during ripening and overripening of sweet cherry. HortScience 25 (7): 777778.

7. Hallett I C, Macrae E A and Wegrzyn T F (1992). Changes in kiwifruit cell wall ultrastructure and cell packing during postharvest ripening. Int. J. Plant Sci. 153 (1): 49-60.

8. Hardy P J (1967). Sucrose breakdown and synthesis in the ripening grape berry. Aust. J. Biol. Sci. 20: 465-470.

9. Hifny H A A (1972). Untersuchungen zur Stiellähme der Reben. I. Die Symptomataologie der Krankheit. Vitis 10: 298-313.

10. Kriedemann P E (1969). Sugar uptake by grape berry: a note on the absorption pathway. Planta 85: 111-117.

11. Marschner P (ed.) (2011). Marschner's Mineral Nutrition of Higher Plants. Academic Press. ISBN: 978-0-12384905-2.
12. Marschner H and Mengel K (1966). Der Einfluß von Ca- und $\mathrm{H}$-Ionen bei unterschiedlichen Stoffwechselbedingungen auf die Membranpermeabilität junger Gerstenwurzeln. Z. Pflanzenern. und Bodenkunde 112, 39-49.

13. Mengel K and Kirkby E A (2007). Principles of Plant Nutrition. International Potash Institute, WorblaufenBern, Switzerland. $3^{\text {rd }}$ ed.

14. Pirie A J G and Mullins M G (1980). Concentration of phenolics in the skin of grape berries during fruit development and ripening. Am. J. Enol. Vitic. 31: 34-36.

15. Pooviah B W (1979). Role of calcium in ripening and senescence. Comm. Soil Sci. Plant Anal. 10, 83-88.

16. Solomos T and Laties G G (1973). Cellular organization and fruit ripening. Nature, 245: 390-391.

17. Souci S W, Fachmann W, Kraut H. (2008). Food Composition and Nutrition Tables. 7th Ed., Wissenschaftliche Verlagsgesellschaft Stuttgart.

18. Stellwaag-Kittler F (1967). Die Stiellähme der Trauben. Dt. Weinbau 18: 1048

19. Suwwan M A and Poovaiah B W (1978). Association between elemental content and fruit ripening in rin and normal tomatoes. Plant Physiol. 61: 883-885.

20. Theiler R (1986). Beziehungen zwischen Klimafaktoren und dem Stiellähmebefall bei Riesling x Sylvaner. Vitis 25: 8-20.

21. Tuteja N, Mahajan S (2007). Calcium signaling network in plants. Plant Signaling \& Behavior 2: 79-85.

22. Ulrich R (1952). La vie des fruits. Masson Ed. Paris.

23. Usseglio-Tomasset L (1989). Chimie Oenologique. TecDocLavoisier, Paris.

24. Würdig G and Woller R (1989). Chemie des Weines. Verlag Eugen Ulmer Stuttgart. 